\title{
Antioxidative Activity of Zinc-Enriched Saccharomyces cerevisiae FF-10 in In vitro Model Systems
}

\author{
Jae Young Cha', Bo Kyung Park, Hee Young Ahn, Kyung Eun Eom, Bang Sil Jun and Young Su Cho* \\ Department of Biotechnology, Dong-A University, Busan 604-7, Korea \\ ${ }^{1}$ Technical Research Institute, Daesun Distilling Co., Ltd. Busan 619-934, Korea
}

Received December 16, 2008 / Accepted February 10, 2009

\begin{abstract}
Zinc is an essential trace element for human and plays an important biological role in antioxidant properties. We have been reported that zinc-enriched S. cerevisiae FF-10 contained $392 \mathrm{mg} \%$ in the YM basal and 3,193 $\mathrm{mg} \%$ in the YM optimal medium. Antioxidative activity of FF-10 was tested in vitro models by DPPH ( $\alpha, \alpha^{\prime}$-diphenyl- $\beta$-picrylhydrazyl) radical scavenging activity and lipid peroxidation using linoleic acid (LA) and rat liver homogenate. DPPH radical scavenging activity was higher in the cell-free extract of FF-10 cultured in the YM optimal medium (YMOM) than that in the YM basal medium (YMBM). The inhibition activity of lipid peroxidation using rat liver homogenate was shown in the following order: BHT > YMOM > YMBM and these values were dose dependently. The lipid peroxidation of the control mixture by ferric thiocyanate and TBA methods using LA was increased rapidly as typical peroxidation curve of LA from one day and the antioxidation activity of the cell free extracts by cultivating FF-10 in the YMOM were higher than that of the YMBM. Result of this study indicate that the cell-free extracts containing a high intercellular zinc of S. cerevisiae FF-10 cultured in YMOM showed strong antioxidation capacities in DPPH radical scavenging activity and lipid peroxidation using LA and rat liver homogenate.
\end{abstract}

Key words : Antioxidation, zinc, S. cerevisiae FF-10, DPPH, lipid peroxidation

\section{Introduction}

Zinc is an essential trace element of all organisms [31]. Zinc plays important roles in various physiologic functions in growth, development, and sexual maturity in males $[16,21]$. Zinc also plays biological roles in antioxidant properties, lipid metabolism, insulin resistance, immune response, sperm physiology and hepatic injury [3,26,34,39]. The recommended dairy intake of zinc is $10 \mathrm{mg}$ per day in Japan and $15 \mathrm{mg}$ in the USA $[23,37]$. The current estimate is that a nutritional deficiency of zinc may affect over 2 billion subjects in the developing world and $18 \%$ of people in the USA consume less than half the recommended levels of zinc [21]. Clinical zinc deficiency causes various clinical problem, such as growth retardation and taste impairment [29,37]. The main cause of zinc deficiency in human is nutritional.

Yeast has long been utilized in areas of food, medicine and cosmetic industry due to their bioactive and nutritional components, such as amino acids, peptides, zinc, beta-glucan, glutathione, cerebroside, and terrein $[8,10,25,28]$. Zinc

\footnotetext{
*Corresponding author

Tel : +82-51-200-7586, Fax : +82-51-200-7505

E-mail : choys@dau.ac.kr
}

has shown hepatoprotective effect against hepatotoxin and antioxidant properties against oxidative damage in organisms $[4,19,34,35]$. We also recently have been reported that highly zinc containing yeast strain isolated from the tropical fruit rambutan and this strain was protected against alcohol-induced hepatotoxicity and oxidative stress in rats $[10,11]$.

The many kinds of natural antioxidants from microorganisms have been isolated by using various screening systems $[12,24]$. The antioxidative substances were also produced intercellularly into S. cerevisiae IFO 2114 and extracellularly into the culture medium by Aspergillus soja and Aspergillus oryzae [22,36]. We also have been reported that an intercellularly antioxidative activities found in the Bacillus sp. FF-7 and a glutathione-enriched producing yeast strain Saccharomyces cerevisiae FF-8 $[12,27]$. However, there is very limited information on the capacities of this high zinc-containing yeast strain S. cerevisiae FF-10 on the antioxidation properties against lipid peroxidation. Thus, the antioxidation activity of the zinc-enriched cell-free extracts from S. cerevisiae FF-10 was tested in vitro experimental models, DPPH radical scavenging activity, ferric thiocyanate and thiobarbituric acid reacting substances (TBARS) methods against the lipid peroxidation of rat liver homogenate and LA. 


\section{Materials and Methods}

\section{Yeast strain culture conditions}

We have been reported that highly zinc containing yeast strain, S. cerevisiae FF-10 (KACC 93071), was isolated from the tropical fruit rambutan [13] and this strain contained 392 $\mathrm{mg} \%$ and 3,193 $\mathrm{mg} \%$ zinc concentrations in the YM basal and optimal mediums, respectively. Zinc-enriched yeast strain FF-10 was aerobically cultivated either in the YMBM (glucose $1.0 \%$, peptone $0.3 \%$, yeast extract $0.3 \%$, malt extract $0.3 \%)$ and YMOM $(2.0 \%(\mathrm{w} / \mathrm{v})$ glucose, $5.0 \%$ yeast extract, and $0.04 \% \mathrm{ZnCl}_{2}$ ) with $100 \mathrm{rpm}$ shaking at $30^{\circ} \mathrm{C}$ for $72 \mathrm{hr}$. After incubation, the culture was centrifuged at $7,000 \times g$ for $15 \mathrm{~min}$, the supernatant was removed, and the yeast cells was washed with distilled water three times. The harvested yeast cells were suspended in $0.2 \mathrm{M}$ phosphate buffer $(\mathrm{pH}$ 7.2) and disrupted by sonication. The disrupted cells were then removed by centrifugation, and the cell-free extract was concentrated by an evaporator, followed by lyophilization. The powder obtained was dissolved in water and used for in vitro antioxidation activity measurement.

\section{DPPH radical scavenging activity assay}

Antioxidation activity was determined based on the free radical scavenging activity of the experimental compounds [6,7]. DPPH (16 mg) was dissolved in $100 \mathrm{ml}$ ethanol and this solution was filtered with Whatman filter paper No. 2. After mixing $1 \mathrm{ml}$ of DPPH solution with $5 \mathrm{ml}$ of $0.05 \%$ $(\mathrm{w} / \mathrm{v})$ the FF-10 cell-free extract, for $30 \mathrm{~min}$ incubation period at room temperature, the optimal density (OD) was measured at $528 \mathrm{~nm}$. The antioxidant activity was expressed as the absorbance and were calculated according to the following equation: [DPPH radical scavenging activity $(\%)=$ (control OD-sample OD)/control OD×100]. 0.05\% (w/v) BHT was used as positive control and, which is one of the most widely used chemicals to retard oxidation $[15,27]$.

Determination of lipid peroxidation using rat liver homogenate

The liver homogenate prepared from the normal diet feeding rats was used to analyze the concentrations of TBARS. The lipid peroxidation in rat liver homogenate induced with $0.2 \mathrm{mM} \mathrm{Fe}^{2+}$ and $0.25 \mathrm{mM}$ ascorbate was measured as concentrations of TBARS by the previously described method with a minor modification [32]. Rat liver homogenates containing $\mathrm{Fe}^{2+}$ and ascorbate with or without the $0.05 \%(\mathrm{w} / \mathrm{v})$ cell-free extract, were placed in a shaking water bath at $37^{\circ} \mathrm{C}$ for $30 \mathrm{~min}$. And then equal volumes of $0.75 \%$ TBA and 15\% trichloroacetic acid were added. Reaction mixtures were heated at boiling water for $30 \mathrm{~min}$, and after cooling in ice-water, centrifuged for $10 \mathrm{~min}$ at 3,000 rpm to separate corpusculated particles. The absorbance of the supernatant was read at $532 \mathrm{~nm}$. The antioxidant activity for TBARS formation was expressed as the absorbance. $0.05 \%$ BHT was used as positive control.

\section{Determination of lipid peroxidation using linoleic} acid

Lipid peroxidation using linoleic acid was determined by TBA bound malondialdehyde. The TBA method was used for lipid peroxidation of the LA in $\mathrm{Fe}^{2+}$-ascorbate system as the oxidative catalysis $[17,18]$. The $0.05 \%$ (w/v) FF-10 cell-free extract was added to a solution of LA $0.13 \mathrm{ml}$, ethanol $10 \mathrm{ml}, 0.01 \% \mathrm{FeSO}_{4} 0.2 \mathrm{ml}, 0.01 \%$ ascorbate $0.2 \mathrm{ml}$, and $0.2 \mathrm{M}$ phosphate buffer ( $\mathrm{pH} 7.0) 10 \mathrm{ml}$. The total reaction volume was adjusted to $20 \mathrm{ml}$ with deionized distilled water, and the reaction mixture was incubated at $40^{\circ} \mathrm{C}$ in the dark during up to 7 days. Every day, $0.2 \mathrm{ml}$ of incubated reaction solution was mixed with $0.05 \mathrm{ml}$ of $7.2 \%$ butylated hydroxytoluene and $2 \mathrm{ml}$ of $20 \mathrm{mM}$ TBA/15\% trichloroacetic acid. The sample was mixed using a vortex, and incubated in a boiling water bath for $30 \mathrm{~min}$ to develop color. After cooling in cold water, the samples were centrifuged at $3,000 \times g$ for $15 \mathrm{~min}$ and the absorbance of the resulting upper layer was measured at $500 \mathrm{~nm}$. Deionized distilling water was substituted for FF-10 cell-free extracts in the blank samples.

\section{Results and Discussion}

\section{DPPH-free radical scavenging activity}

The ability of zinc to retard oxidative processes has been recognized for many years. The FF-10 cell free extract containing zinc as antioxidative substance cultured in both the YMBM and the YMOM were evaluated for antioxidant activity by in vitro experimental methods. The free radical scavenging activity measurement using discoloration of DPPH has been widely used due to its stability, simplicity, and reproducibility $[1,2]$. Generally, natural antioxidants such as glutathione, tocopherol, phenolic-compounds, demonstrated greater antioxidant action in DPPH free radical scavenging activity $[7,14,15,27,40]$. A significant positive relationship between these compounds and DPPH radical scavenging activ- 
ity was observed [40]. In this regard, we also reported that the DPPH radical scavenging activity of the glutathione produced by S. cerevisiae FF-8 is as high as $0.05 \%$ (w/v) BHT. The DPPH radical scavenging activity of the cell free extracts of zinc-enriched FF-10 cultured in the YMOM was higher than that of the YMBM (Fig. 1). However, BHT $(0.05 \%)$ used as the most widely a positive control showed the highest antioxidation activity under this study conditions.

Inhibition of lipid peroxidation using the rat liver homogenate

Zinc plays a sacrificial defense role against oxidative damage in organisms $[19,34]$. The inhibition activity of metal ion $\mathrm{Fe}^{2+}$-catalyzed lipid peroxidation by the ferric TBA method using tissues has been widely used due to in vivo membrane damage attributed to lipid oxidation $[9,15,27,32]$. Hence, present study examined the inhibitory effect of zinc-enriched FF-10 on lipid peroxidation in $\mathrm{Fe}^{2+}$-catalyzed system using rat liver homogenate. An inhibition activity was shown in the following order: BHT > YMOM > YMBM and these were dose-dependent (Fig. 2). As expected, BHT used as positive control showed the highest antioxidation activity. This antioxidation effect was more pronounced in strain cultured in the YMOM than that in the YMBM. This result indicate that zinc in FF-10 strain is an antioxidation substance and functioned effectively as natural antioxidant.

\section{Inhibition of lipid peroxidation using linoleic acid}

The antioxidation activity of the cell-free extract of FF-10

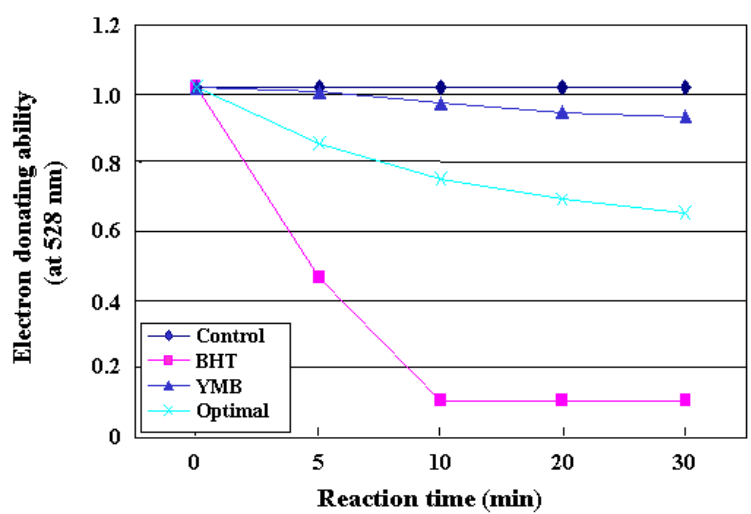

Fig. 1. The DPPH free radical scavenging activity of the cell-free extracts of a high zinc S. cerevisiae FF-10 cultured in both the YMBM and the YMOM. BHT: butylated hydroxytoluene $(0.05 \%)$ YMBM was contained $1.0 \%(\mathrm{w} / \mathrm{v})$ glucose, $0.3 \%$ peptone, $0.3 \%$ yeast extract, and $0.3 \%$ malt extract. YMOM was contained 2.0\% (w/v) glucose, 5.0\% yeast extract, and $0.04 \% \mathrm{ZnCl}_{2}$.

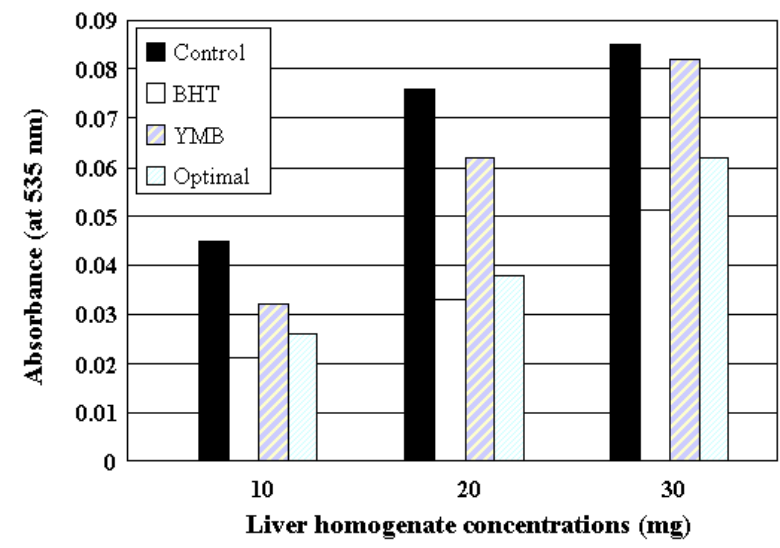

Fig. 2. Antioxidative activity of the cell-free extracts of a high zinc S. cerevisiae FF-10 cultured in both the YMBM and the YMOM against the lipid peroxidation of the rat liver homogenate as measured by the TBARS method. BHT: butylated hydroxytoluene $(0.05 \%)$ YMBM was contained $1.0 \%(\mathrm{w} / \mathrm{v})$ glucose, $0.3 \%$ peptone, $0.3 \%$ yeast extract, and $0.3 \%$ malt extract. YMOM was contained $2.0 \%(\mathrm{w} / \mathrm{v})$ glucose, $5.0 \%$ yeast extract, and $0.04 \% \mathrm{ZnCl}_{2}$.

was measured based on the inhibition of LA peroxidation by the ferric thiocyanate and TBA methods in this study. As shown in Fig. 3 and 4, the production of LA peroxide in the control increased rapidly from the first day and this increase continued until upto seven days. However, the cell-free extract of FF-10 cultured in the YMOM showed an antioxidation effect of inhibiting lipid peroxidation compared with the control. BHT showed the highest antioxidation activity under this study conditions. Present

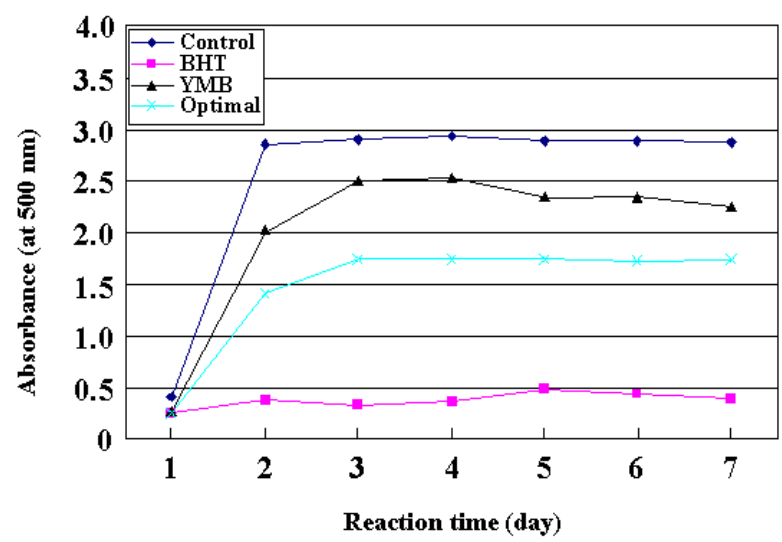

Fig. 3. Antioxidative activity of the cell-free extracts of a high zinc S. cerevisiae FF-10 cultured in both the YMBM and the YMOM against the linoleic acid oxidation measured by the ferric thiocyanate method. BHT: butylated hydroxytoluene $(0.05 \%)$ YMBM was contained $1.0 \%(\mathrm{w} / \mathrm{v})$ glucose, $0.3 \%$ peptone, $0.3 \%$ yeast extract, and $0.3 \%$ malt extract. YMOM was contained $2.0 \%(\mathrm{w} / \mathrm{v})$ glucose, $5.0 \%$ yeast extract, and $0.04 \% \mathrm{ZnCl}_{2}$. 


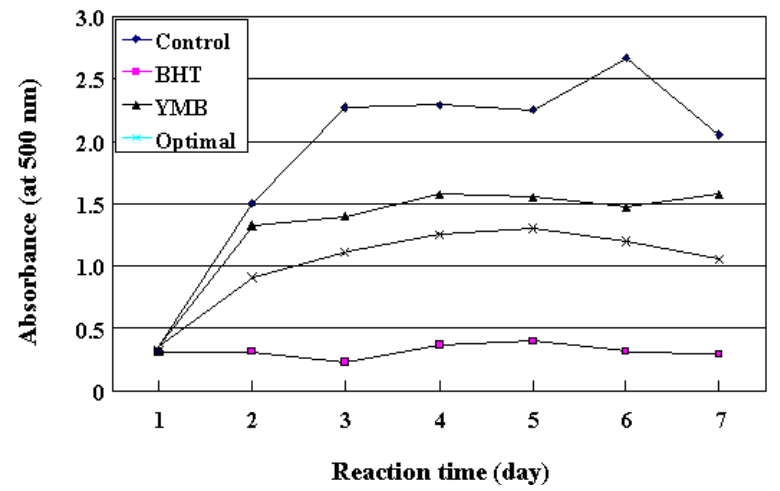

Fig. 4. Antioxidative activity of the cell-free extracts of a high zinc S. cerevisiae FF-10 cultured in both the YMBM and the YMOM against the lipid peroxidation measured by the ferric TBA method. BHT: butylated hydroxytoluene $(0.05 \%)$ YMBM was contained $1.0 \%(\mathrm{w} / \mathrm{v})$ glucose, $0.3 \%$ peptone, $0.3 \%$ yeast extract, and $0.3 \%$ malt extract. YMOM was contained $2.0 \%(\mathrm{w} / \mathrm{v})$ glucose, $5.0 \%$ yeast extract, and $0.04 \% \mathrm{ZnCl}_{2}$.

results concluded that the cell-free extract of $S$. cerevisiae FF-10 cultured in the YMOM had stronger antioxidative capacity than that of the YMBM against the LA peroxidation.

Results of this study suggest the utility of the zinc-enriched S. cerevisiae FF-10 for various nutritional products including antioxidant for use as health food or nutraceutical supplement as an antioxidant.

\section{Acknowledgement}

This study was supported by research funds from Dong-A university.

\section{References}

1. Abe, N., T. Murata, and A. Hirota. 1998. Novel DPPH radical scavengers, bisorbicillinol and demethyltrichodimerol, from a fungus. Biosci. Biothecnol. Biochem. 62, 661-666.

2. Al-Saikhan, M. S., L. R. Howard, and J. C. Miller Jr. 1995. Antioxidant activity and total phenolics in different genotypes of potato (Solanum tuberosum L.). J. Food Sci. 60, 341343.

3. Baltaci, A. K., R. Mogulkoc, and A. Ozturk. 2006. Testosterone and zinc supplementation in castrated rats: Effects on plasma leptin levels and relation with $\mathrm{LH}, \mathrm{FSH}$ and testosterone. Life Sci. 78, 746-752.

4. Bao, B., A. S. Prasad, F. W. Beck, D. Snell, A. Suneja, F. H. Sarkar, N. Doshi, J. T. Fitzgerald, and P. Swerdlow. 2008. Zinc supplementation decreases oxidative stress, incidence of infection, and generation of inflammatory cyto- kines in sickle cell disease patients. Transl. Res. 152, 67-80.

5. Bertelsen, G., C. Christophersen, P. H. Nielsen, H. L. Madsen, and P. Stadel. 1995. Chromatographic isolation of antioxidants guided by a methyl linoleate assay. J. Agric. Food Chem. 43, 1272-1275.

6. Blois, M. S. 1958. Antioxidant determination by the use of a stable free radical. Natu. 26, 1199-1200.

7. Brand-Williams, W., M. E. Cuvelier, and C. Berset. 1995. Use of a free radical method to evaluate antioxidant activity. Lebensm. Wiss. Technol. 28, 25-30.

8. Cha, J. Y., J. C. Park, B. S. Jeon, Y. C. Lee, and Y. S. Cho. 2004. Optimal fermentation conditions for enhanced glutathione production by Saccharomyces cerevisiae FF-8. J. Microbiol. 42, 51-55.

9. Cha, J. Y., H. J. Kim, and Y. S. Cho. 2000. Effects of water-soluble extract from leaves of Morus alba and Cudrania tricuspidata on the lipid peroxidation in tissues of rats. J. Korean Soc. Food Sci. Nutr. 29, 531-536.

10. Cha, J. Y., J. S Heo, B. K. Park, and Y. S. Cho. 2008. Effect of zinc-enriched yeast supplementation on serum zinc and testosterone concentrations in ethanol feeding rats. J. Life Sci. 18, 947-951.

11. Cha, J. Y., J. S. Heo, and Y. S. Cho. 2008. Effect of zinc-enriched yeast FF-10 strain on the alcoholic hepatotoxicity in alcohol feeding rats. Food Sci. Biotechnol. 17, 1207-1213.

12. Cha, J. Y, H. J. Kim, B. S. Jun, J. C. Park, M. Ok, and Y. S. Cho. 2003. Antioxidative activities and produced condition of antioxidative substance by Bacillus sp. FF-7. J. Korean Soc. Agric. Chem. Biotechnol. 46, 165-170.

13. Cha, J. Y., J. S. Heo, J. W. Kim, S. W. Lee, and Y. S. Cho. 2008. Isolation and identification of zinc-enriched yeast Saccharomyces cerevisiae FF-10 from the tropical fruit rambutan. J. Life Sci. 18, 144-453.

14. Cha, J. Y. and Y. S. Cho. 1999. Effect of potato polyphenolics on lipid peroxidation in rats. J. Korean Soc. Food Sci. Nutr. 28, 1131-1136.

15. Cha, J. Y. and Y. S. Cho. 2001. Antioxidative activity of extracts from fruit of Cudrania tricuspiata. J. Krean Soc. Food Sci. Nutr. 30, 547-551.

16. Daz-Gmez, N. M., E. Domnech, F. Barroso, S. Castells, C. Cortabarra and A. Jimnez. 2003. The effect of zinc supplementation on linear growth, body composition, and growth factors in preterm infants. Pediatrics 111, 1002-1009.

17. Decker, E. and H. Faraji. 1990. Inhibition of lipid oxidation by carnosine. JAOCS 67, 650-652.

18. Farmer, E. H., A. Bloomfield, A. Sundralingan, and D. A. Sutton. 1942. The couse and mechanism of autoxidation reactions in olefinic and polyolefinic substances, including rubber. Trans Faraday Soc. 38, 348-356.

19. Goel, A., V. Dani, and D. K. Dhawan. 2005. Protective effects of zinc on lipid peroxidation, antioxidant enzymes and hepatic histoarchitecture in chlorpyrifos-induced toxicity. Chem. Biol. Interact 156, 131-140.

20. Halliwell, B. and J. M. C. Gutteridge. 1990. Role of free radicals and catalyticmetal ions in human disease: an overview. Methods in Enzymol. 186, 1-85. 
21. Ho, E. and B. Ames. 2003. Zinc deficiency induces DNA damage and compromises DNA repair signal pathways in C6 glioma cells. J. Nutr. 133, (Supple) 203E-282E.

22. Kato, F., I. Nakazato, A. Murata, S. Okamoto, and Y. Yone. 1986. Utilization of waste fish treatment with microorganisms. Part II. Use of waste fish from large scale production of fermented fish meal and its feed efficiency. Nippon Nogeikagaku Kaishi 60, 287-293.

23. Kenko Eiyo Joho Kenky-Kai. 1999. Sixth Revised Recommended Daily Allowances and Dietary Refernce Intake. Daiichi Shuppan, Tokyo, Japan.

24. Kim, W. G., J. P. Kim, and I. D. Yoo. 1996. Benzastatins A, B, C, and D: new free radical scavengers from Streptomyces nitrosporeus 30643. II. Structural determination. J. Antibiotics 49, 26-30.

25. Kinosita, M., N. Hory, K. Aida, T. Sugawara, and M. Ohnish. 2007. Prevention of melanin formation by yeast cerebroside in B16 melanoma cells. J. Oleo Sci. 56, 645-648.

26. Kumar, N., R. P. Verma, L. P. Singh, V. P. Varshney, and R. S. Dass. 2006. Effect of different levels and sources of zinc supplementation on quantitative and qualitative semen attributes and serum testosterone level in crossbred cattle (Bos indicus x Bas Taurus) bulls. Reprod. Nutr. Dev. 46, 663-675.

27. Lee, C. H., J. Y. Cha, H. J. Lee, Y. C. Lee, Y. L. Choi, and Y. S. Cho. 2005. The antioxidative activity of glutathioneenriched extract from Saccharomyces cerevisiae FF-8 in vitro model system. J. Life Sci. 15, 819-825.

28. Lee, S., W. G. Kim, E. S. Kim, I. J. Ryoo, H. K. Lee, J. N. Kim, S. H. Jung, and I. D. Yoo. 2005. Synthesis and melanin biosynthesis inhibitory activity of $( \pm)$-terrein produced by Penicillium sp. 20135. Bioorg. Med. Chem. Lett 15, 471-473.

29. Maia, R., F. Debora, D. Slivia, and C. Nestor. 2007. Copper- and zinc-enriched mycellium of Agricus blazei Murrill: Bioaccumulation and bioavailability. J. Med. Food
10, 175-183.

30. Mungan, A. G., M. Can, S. Açikgöz, E. Eştürk, and C. Altinyazar. 2006. Lipid peroxidation and homocysteine levels in Behçet's disease. Clin. Chem. Lab. Med. 44, 1115-1118.

31. Murakami, M. and T. Hirano. 2008. Intracellular zinc homeostasis and zinc signaling. Cancer Sci. 99, 1515-1522.

32. Ohkawa, H., N. Ohishi, and K. Yagi. 1979. Assay for lipid peroxides in animal tissues by thiobarbituric acid reaction. Anal. Biochem. 95, 351-358.

33. Pacifici, R. E. and K. J. Davies. 1991. Protein, lipid, and DNA repair systems in oxidative stress: the free-radical theory of aging revisited. Gerontol. 37, 166-180.

34. Powell, S. 2000. The antioxidant properties of zinc. J. Nutr. 130, 1447S-1454S.

35. Prasad, A. S., B. Bao, F. W. Beck, O. Kucuk, and F. H. Sarkar. 2004. Antioxidant effect of zinc in humans. Free Radic. Biol. Med. 37, 1182-1190.

36. Rashid, M. H., F. Kato, and A. Murata. 1992. Effect of microorganism on the peroxidation of lipid and fatty acid composition of fermented fish meal. Biosci. Biotechnol. Biochem. 56, 1058-1061.

37. Sandstead, H. H. 1995. Is zinc deficiency a public health problem? Nutr. 11, 87-92.

38. Shon, M. H., J. Y. Cha, C. H. Lee, S. H. Park, and Y. S. Cho. 2007. Protective effect of administrated glutathioneenriched Saccharomyces cerevisiae FF-8 against carbon tetrachloride $\left(\mathrm{CCl}_{4}\right)$-induced hepatotoxicity and oxidative stress in rats. Food Sci. Biochenol. 16, 967-974.

39. Tallman, D. L. and C. G. Taylor. 2003. Effects of dietary fat and zinc on adiposity, serum leptin and adipose fatty acid composition in C57BL/6J mice. J. Nutr. Biochem. 14, $17-23$.

40. Xin, Z., K. S. Song, and M. R. Kim. 2004. Antioxidant activity of salad vegetables grown in Korean. J. Food Sci. Nutr. 9, 289-294. 
초록 : 아연-고함유 효모 Saccharomyces cerevisiae FF-10 세포액의 항산화효과

차재영 $A^{1}$ 박보경 $\cdot$ 안희영 $\cdot$ 엄경은 · 전방실 · 조영수*

(동아대학교 생명공학과, ${ }^{1}$ 대선주조(주) 기술연구소)

아연 고함유 효모 S. cerevisiae FF-10의 항산화능을 검토하기 위하여 DPPH 전자 공여능, linoleic acid을 이용한 ferric thiocyanate법과 TBA법에 의한 과산화지질 생성 정도 및 흰쥐 간 조직 생체막을 이용한 TBARS법에 의한 과산화지질 생성 정도를 측정하였다. 본 실험은 효모 생육배지인 $\mathrm{YM}$ 기본배지와 아연 생산량을 증대시키는 $\mathrm{YM}$ 최적배지에서 각각 배양된 S. cerevisiae FF-10의 세포 파쇄액의 항산화 활성을 비교하였다. DPPH 전자 공여능은 양성 대조구로 사용한 BHT에서 가장 높았고, YM 기본배지 보다는 YM 최적배지에서 배양된 FF-10 세포 파쇄액에 서 항산화 활성이 높게 나타났다. 간 조직 생체막 과산화지질 생성 정도는 BHT > 최적 생산배지 > 기본배지 순으로 저해되었다. Linoleic acid를 이용한 과산화지질 생성정도는 음성 대조구에서 반응 1 일째부터 급격히 증가한 후 반응종료일까지 계속 그 수준이 유지되었고, 양성 대조구인 BHT 처리구에서는 과산화지질 생성이 억제되어 높은 항산화활성이 확인되었으며, YM 기본배지 보다는 YM 최적배지에서 높은 과산화지질 생성 저해활성을 보였 다. 이상의 결과에서 in vitro 항산화 실험계인 DPPH radical scavenging activity, 간 조직 생체막과 linolic acid 지방산을 이용한 ferric thiocyanate and TBARS 측정에서 항산화 활성은 양성 대조구인 BHT 보다는 낮았으나 최적배지에서 배양된 아연 고함유 효모 S. cerevisiae FF-10 균주의 세포 파쇄액에서 모두 높게 나타나 in vivo 항산화 실험계에서도 확인이 필요한 것으로 사료되어 진다. 